\title{
EGF wt Allele
}

National Cancer Institute

\section{Source}

National Cancer Institute. EGF wt Allele. NCI Thesaurus. Code C51421.

Human EGF wild-type allele is located within 4q25 and is approximately $99 \mathrm{~kb}$ in length.

This allele, which encodes pro-epidermal growth factor precursor protein, plays a role in differentiation and proliferation. 